\title{
Time Course of Appearance and Disappearance of Human Mast Cell Tryptase in the Circulation after Anaphylaxis
}

\author{
L. B. Schwartz, * J. W. Yunginger, ${ }^{\star}$ J. Miller, * R. Bokhari, ${ }^{\star}$ and D. Dull* \\ *Department of Medicine, Medical College of Virginia, Virginia Commonwealth University, Richmond, Virginia 23298; \\ and ${ }^{\ddagger}$ Allergic Diseases Research Laboratory, Mayo Medical School, Rochester, Minnesota 55905
}

\begin{abstract}
Tryptase, a neutral protease of human mast cells, is a potentially important indicator of mast cell involvement in various clinical conditions. The current study examined the time course of appearance and disappearance of tryptase in the circulation after an anaphylactic event and the stability of both endogenous and exogenous tryptase in terms of freeze-thawing and temperature. The peak level of tryptase after an experimentally induced systemic anaphylactic reaction occurred 1-2 h after the initiating bee sting in each of three subjects, in contrast to histamine levels which peaked at 5-10 $\mathrm{min}$. In some cases elevated levels of tryptase may not be detected during the initial 15-30 min. Tryptase levels then declined under apparent first order kinetics with a $t_{1 / 2}$ of $\sim 2 \mathrm{~h}$. Similar disappearance kinetics were observed for two subjects presenting in the emergency room with immediate type reactions, one with severe asthma after indomethacin ingestion, the other with systemic anaphylaxis after a bee sting. Histamine levels declined rapidly and were back to baseline by $15-60 \mathrm{~min}$. Measured levels of tryptase in serum or plasma were not diminished by up to four freeze-thaw cycles. Incubation of serum samples taken from subjects with elevated levels of tryptase at 22 and $37^{\circ} \mathrm{C}$ indicated that $>50 \%$ of endogenous tryptase was still detected after $4 \mathrm{~d}$. Purified tryptase added to serum or plasma and incubated as above was less stable: $\sim 50 \%$ of exogenous tryptase in serum and $\sim 15 \%$ in plasma was detected after $2 \mathrm{~d}$ of incubation. Therefore, optimally samples should be stored frozen, but even those stored at room temperature for up to $4 \mathrm{~d}$ should be satisfactory. The best time to obtain samples for tryptase determinations is 1-2 $\mathrm{h}$ after the precipitating event, but depending on the magnitude of the initial response elevated levels of tryptase may be present in the circulation for several hours.
\end{abstract}

\section{Introduction}

In order for tryptase levels in the circulation to be used optimally as an indication of mast cell activation, the time course of appearance and disappearance of the enzyme after mast cell activation needs to be established. Tryptase levels by immunoassay previously have been shown to be elevated $1-4 \mathrm{~h}$ after a systemic anaphylactic event in 6 of 6 subjects and in 11 of 17

Address reprint requests to Dr. Lawrence B. Schwartz, Medical College of Virginia, MCV Station, Box 263, Richmond, VA 23298-0263.

Received for publication 10 November 1988 and in revised form 28 December 1988.

J. Clin. Invest.

(C) The American Society for Clinical Investigation, Inc.

0021-9738/89/05/1551/05 \$2.00

Volume 83, May 1989, 1551-1555 subjects with nonacute systemic mastocytosis, but not in control groups, including patients with septic or myocardial shock (1). Tryptase is the major known protein component of mast cell secretory granules (2-4), being present in both $\mathrm{MC}_{\mathrm{T}}$ (mucosal) and $\mathrm{MC}_{\mathrm{TC}}$ (connective tissue) types of human mast cells $(5,6)$. Because negligible amounts of the enzyme are present in basophils (7), unlike histamine, tryptase levels selectively indicate involvement of mast cell activation. Further, because histamine may be released in vitro from basophils during blood coagulation, only carefully collected plasma should be used for histamine determinations. In contrast, tryptase determinations appear to be equally valid in serum or plasma. In addition, a consequence of the relatively short $t_{1 / 2}$ (minutes) of histamine or histamine metabolites in the circulation is that within $1 \mathrm{~h}$ after an immediate type reaction, plasma levels normally will have returned to baseline, limiting the clinical practicality of such measurements $(8-10)$.

The $t_{1 / 2}$ for disappearance of tryptase from the circulation previously was estimated to be several hours (1), but only a limited number of time points were assessed. In the current study samples from patients experiencing systemic anaphylactic reactions to hymenoptera sting challenges $(n=4)$ and indomethacin ingestion $(n=1)$ were collected at multiple time points and analyzed for tryptase and, in several cases, for histamine.

\section{Methods}

Patients. Participants in the tryptase time course study included two patients presenting to the emergency room at the Medical College of Virginia who agreed to provide hourly blood samples (serum). One presented with systemic anaphylaxis after a bee sting; another with severe asthma after indomethacin ingestion. In addition, plasma samples were obtained from an indwelling venous line before and after diagnostic bee sting challenges, which were performed at the Mayo Clinic with written informed consent as reported previously (11) Serum samples from four different patients also were selected for studies of immunoreactive tryptase stability. One sample $(128 \mathrm{ng} / \mathrm{ml})$ was obtained from a 31-yr-old white female during an episode of idiopathic systemic anaphylaxis with hypotension. A second sample $(34 \mathrm{ng} / \mathrm{ml})$ was obtained from a 51/2-yr-old white female with myelodysplasia $\sim 1$ $h$ after hypotension began to develop during an operative hip procedure, the presumed sensitivity being to a component in latex or rubber material. A third sample $(600 \mathrm{ng} / \mathrm{ml})$ was obtained from a 59-yr-old white male during an episode of hypotension and flushing, who had presented earlier with osteoporosis and vertebral collapse; consequently, he later had a bone biopsy that showed mastocytomas. The fourth sample $(8 \mathrm{ng} / \mathrm{ml})$ was obtained from a 36 -yr-old black female during recovery from anaphylaxis to a bee sting at the Medical College of Virginia. Plasma samples were analyzed for histamine and tryptase, serum samples for tryptase alone. Patients 2 and 3 will be presented in greater detail in separate studies.

The susceptibility of immunoreactive tryptase levels to freezethawing and to incubation at 22 or $37^{\circ} \mathrm{C}$ also were studied. To plasma and serum samples known to have undetectable levels of tryptase $\sim 50$ 
ng of purified tryptase (2) in the presence and absence of $114 \mathrm{ng}$ heparin/ml was added. In addition, serum collected from four different patients with levels of tryptase previously found to be high were selected at random and examined. A portion of each specimen was subjected to one freeze (to $-75^{\circ} \mathrm{C}$ )-thaw $\left(4^{\circ} \mathrm{C} \times 1 \mathrm{~h}\right)$ cycle per day for 1-4 d. Tryptase levels in all samples were measured in triplicate simultaneously upon completion of the entire experiment. Another two portions were incubated at room temperature and $37^{\circ} \mathrm{C}$, respectively, for time periods up to $4 \mathrm{~d}$ before being assayed in triplicate.

Mediator measurements. Tryptase levels were determined by a sandwich ELISA using murine monoclonal IgG anti-tryptase as the primary antibody and goat polyclonal IgG anti-tryptase as the secondary antibody as reported previously $(1,12)$ except that $10 \mathrm{mM}$ EDTA was included to prevent coagulation. In addition, before immunoassay each plasma/serum sample was subjected to filtration through a $0.22-\mu \mathrm{m}$ filter to remove particulate material that might interfere with the immunoassay. The lower limit of sensitivity using $40 \mu \mathrm{l}$ of plasma or serum per assay was $2.5 \mathrm{ng} / \mathrm{ml}$. Currently we consider levels $\leq 5$ $\mathrm{ng} / \mathrm{ml}$ to be within normal limits (tryptase is undetectable in $>90 \%$ of normal subjects). Levels $\geq 10 \mathrm{ng} / \mathrm{ml}$ are considered to be appreciably elevated, while those between 5 and $10 \mathrm{ng} / \mathrm{ml}$ are minimally elevated. Histamine was determined by a double isotopic radioenzyme technique as described previously (13). The lower limit of detection was 0.1 $\mathrm{ng} / \mathrm{ml}$. Statistical comparisons of mean tryptase levels were performed using a two-tailed test.

\section{Results}

Time course of appearance and disappearance of immunoreactive tryptase in the circulation. Tryptase and histamine determinations were performed in plasma samples collected from the contralateral arm before and after venom challenge on one forearm. The patients illustrated in Fig. 1, $B$ and $C$ each developed profound hypotension associated with pruritus, each re-
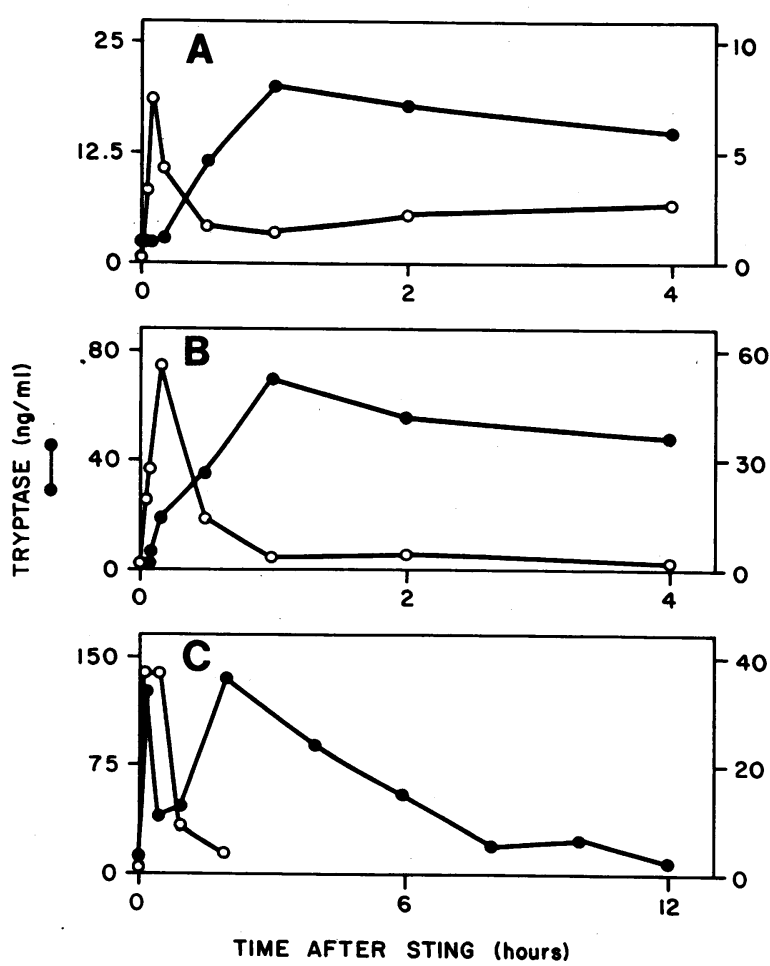

Figure 1. Plasma tryptase (๑) and histamine (O) levels after a bee sting challenge.

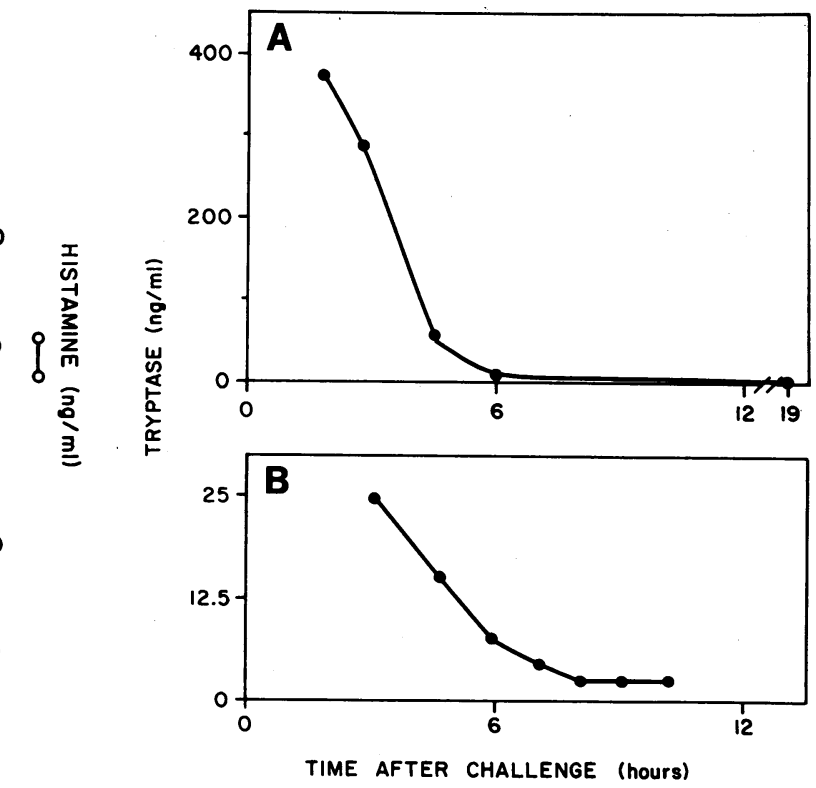

ceived at least two injections of epinephrine along with intravenous fluids, and each recovered by 30-60 min without sequelae. The subject in Fig. $1 A$ developed pruritus and moderate inspiratory and expiratory wheezing without a change in BP. The person required two injections of epinephrine and was back to baseline by $60 \mathrm{~min}$. In each case histamine levels increased over baseline, reached a peak by 5-10 min after challenge, and declined to essentially baseline levels by 30-40 min. Respective levels of tryptase in two of these patients were not detectably elevated until 15 and $30 \mathrm{~min}$ after challenge, reached a maximum at 1 and $2 \mathrm{~h}$, and then declined with a $t_{1 / 2}$ of 1.5 and $2 \mathrm{~h}$. In each case the clinical condition had returned to normal at the time of the peak level of tryptase. The third subject produced a biphasic pattern of tryptase levels with an initial peak at $15 \mathrm{~min}(5 \mathrm{~min}$ after the peak of histamine) and a second peak at $2 \mathrm{~h}$; tryptase levels then declined with a $t_{1 / 2}$ of $1.5 \mathrm{~h}$. In each case the decline in tryptase levels approximated apparent first order kinetics.

Tryptase determinations also were made in serum samples sequentially obtained from two patients presenting to the emergency room with systemic anaphylaxis, as shown in Fig. 2. The patient in $A$ presented $60-90$ min after a bee sting with hypotension and urticaria. The initial tryptase level was markedly elevated upon admission and declined with a $t_{1 / 2}$ of $2 \mathrm{~h}$. The patient in $B$ presented with severe asthma that began about $30 \mathrm{~min}$ after ingestion of $75 \mathrm{mg}$ of indomethacin (an unknown portion of which was removed when vomiting occurred at this time point). At no time did hypotension, pruritus, or urticaria develop. Two similar episodes had occurred previously, one after aspirin and another after ibuprofen, the later requiring intubation. $3 \mathrm{~h}$ after treatment with intravenous aminophylline and nebulized metaprel had been started bronchospasm was still severe and blood sample collection was initiated. Initial tryptase levels were clearly elevated and declined with a $t_{1 / 2}$ of $1.5 \mathrm{~h}$.

Figure 2. Serum tryptase levels after development of systemic anaphylaxis in response to a bee sting $(A)$ and severe asthma in response to indomethacin ingestion $(B)$. Values represent the average of duplicate determinations. 
Effect of repeated freezing and thawing and of incubation of tryptase samples at room temperature or $37^{\circ} \mathrm{C}$ on levels of immunoreactive tryptase. Serum samples obtained from four different individuals with elevated levels of tryptase undergoing clinically apparent systemic anaphylaxis along with serum from normal controls to which purified tryptase $(50 \mathrm{ng} / \mathrm{ml})$ had been added were evaluated. A summary of the results is shown in Table I. For determining the effect of freeze-thawing, samples that had been stored at $-75^{\circ} \mathrm{C}$ were thawed on ice, divided into portions, and frozen at $-75^{\circ} \mathrm{C}$. Respective portions of each sample were thawed and refrozen on a daily basis for $4 \mathrm{~d}$ before all samples were thawed and assayed simultaneously. No statistically significant differences in tryptase levels between samples subjected to one vs. two, three, or four freeze-thaw cycles were observed $(P>0.05)$ in 10 of 12 comparisons. In 2 of 12 comparisons (freeze-thaw cycles 2 and 3 for one subject) tryptase levels were 39 and $50 \%$ higher than baseline $(P<0.025)$, but in no case was the level of tryptase substantially or significantly diminished by the freeze-thaw procedure. Two portions from each of the same six samples used above were taken and incubated at room temperature and $37^{\circ} \mathrm{C}$, respectively. Tryptase levels were determined after $1,2,3$, and $4 \mathrm{~d}$ of incubation. As shown in Fig. 3, the effect of incubation at room temperature was minimal, though a tendency toward higher levels of tryptase was noted, particularly in Figs. 3, $B$ and $C$ where the 4-d values were 1.6- and 1.8-fold higher than initial values. Incubation of samples at $37^{\circ} \mathrm{C}$ for 1 $\mathrm{d}$ resulted in similar levels of tryptase to those incubated at room temperature; longer incubations at $37^{\circ} \mathrm{C}$, in general, yielded values of tryptase that were $50-89 \%$ of those at room temperature. Thus, immunoreactive tryptase is reasonably stable in serum for extended periods of time at temperatures of $37^{\circ} \mathrm{C}$ or lower.

Assessment of purified tryptase added to normal serum or plasma is shown in Fig. 4 and Table I. Freeze-thaw experiments revealed that immunoreactive levels of tryptase in serum and plasma remained unchanged after four freeze-thaw cycles. In three separate experiments, levels of tryptase measured in serum and plasma after two, three, and four freezethaw cycles were compared with levels obtained after freezethaw cycle 1 . With plasma, nine of nine comparisons showed no significant differences $(P>0.1)$. With serum, six of nine

Table I. Effect of Freeze-Thaw Cycles on Immunoreactive Levels of Tryptase

\begin{tabular}{cccc}
\hline $\begin{array}{c}\text { Freeze-thaw } \\
\text { cycle no. }\end{array}$ & $\begin{array}{c}\text { Endogenous tryptase } \\
\text { serum }(n=4)\end{array}$ & $\begin{array}{c}\text { Exogenous tryptase } \\
\text { plasma }(n=3)\end{array}$ & Serum $(n=3)$ \\
\hline 1 & 100 & 100 & 100 \\
2 & $109 \pm 10$ & $91 \pm 2$ & $106 \pm 7$ \\
3 & $113 \pm 12$ & $100 \pm 5$ & $106 \pm 16$ \\
4 & $95 \pm 6$ & $97 \pm 5$ & $117 \pm 13$ \\
\hline
\end{tabular}

Tryptase levels were normalized to that of the first freeze-thaw cycle and multiplied by 100 for comparative analyses. The mean of the normalized values at each freeze-thaw cycle $( \pm S E)$ is shown above. Absolute initial levels of endogenous tryptase $( \pm \mathrm{SD})$ were $123 \pm 7$ $\mathrm{ng} / \mathrm{ml}, 28 \pm 1 \mathrm{ng} / \mathrm{ml}, 654 \pm 90 \mathrm{ng} / \mathrm{ml}$, and $7.9 \pm 0.7 \mathrm{ng} / \mathrm{ml}$ in plasma from each of the four patients. Absolute initial levels of exogenous tryptase for each of the three experiments in plasma were 41,43 , and $55 \mathrm{ng} / \mathrm{ml}$, and in serum were 41,37 , and $87 \mathrm{ng} / \mathrm{ml}$.
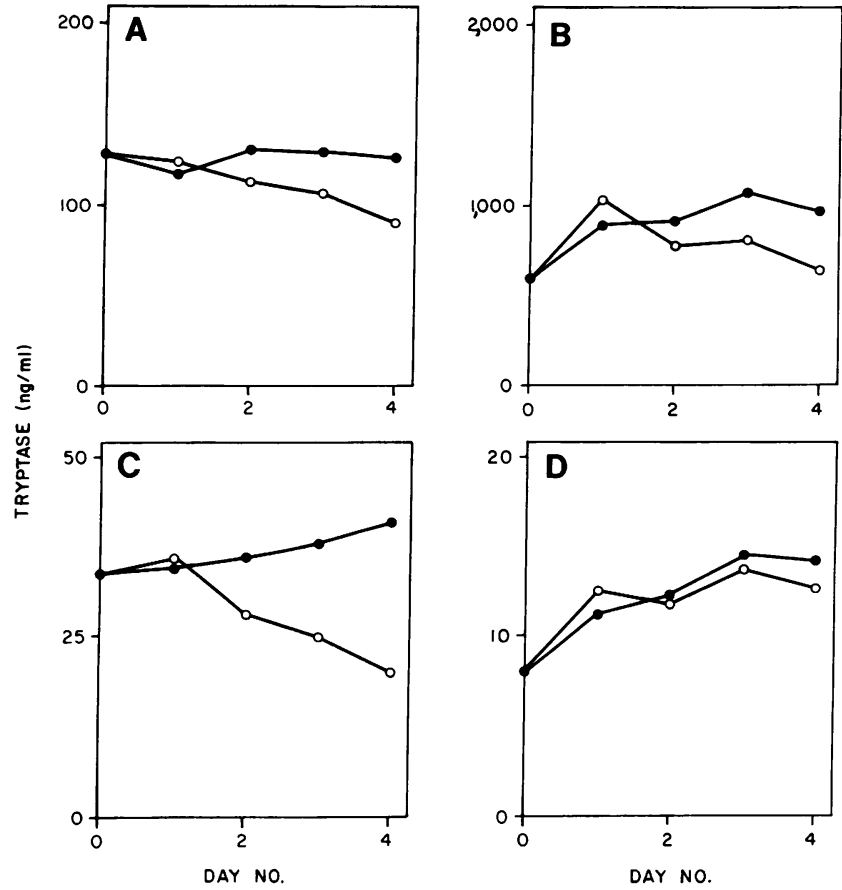

Figure 3. Effect of incubation at $22(\bullet)$ or $37^{\circ} \mathrm{C}(\mathrm{O})$ on endogenous levels of tryptase in serum collected from four separate subjects with clinical systemic anaphylaxis.

comparisons showed no significant differences $(P>0.05)$. In one experiment, samples of freeze-thaw cycles 2,3 , and 4 each appeared to be from 8 to $35 \%$ higher than baseline $(P<0.05)$. In no case was the tryptase level significantly diminished.

Incubation of samples in serum and plasma showed a decline in tryptase levels over a 48 -h period. In serum this decline was less than or equal to $50 \%$ by $48 \mathrm{~h}$, was not appreciably different at 37 than at $22^{\circ} \mathrm{C}$, and was not influenced by heparin. In plasma, tryptase levels declined more rapidly than with serum, and more rapidly at 37 than $22^{\circ} \mathrm{C}$. Heparin markedly slowed this rate of decline.

\section{Discussion}

Tryptase is released in parallel with histamine from activated human mast cells (3), but its appearance in the circulation is delayed relative to that of histamine, presumably due to a slower rate of diffusion away from its tissue site of release. After intradermal challenge with venom, elevated levels of tryptase may not be detected until 30 min later and usually reach a maximum by 1-2 h. In contrast, histamine levels are maximal at 10-15 min after challenge and return to baseline by $30 \mathrm{~min}$, indicating the completion of mast cell degranulation. A similar delayed appearance of tryptase into skin chambers overlying sites of exposed dermis was observed after allergen challenge and also was attributed to a slower rate of diffusion (14). A diffusion-based difference is not surprising given the large size of the tryptase proteoglycan complex relative to soluble histamine, but may also relate to interactions of the enzyme with extracellular tissue components such as heparan sulfate proteoglycan. This proteoglycan is found on cell surfaces and in extracellular matrix material, and compared with heparin proteoglycan has a glycosaminoglycan structure 


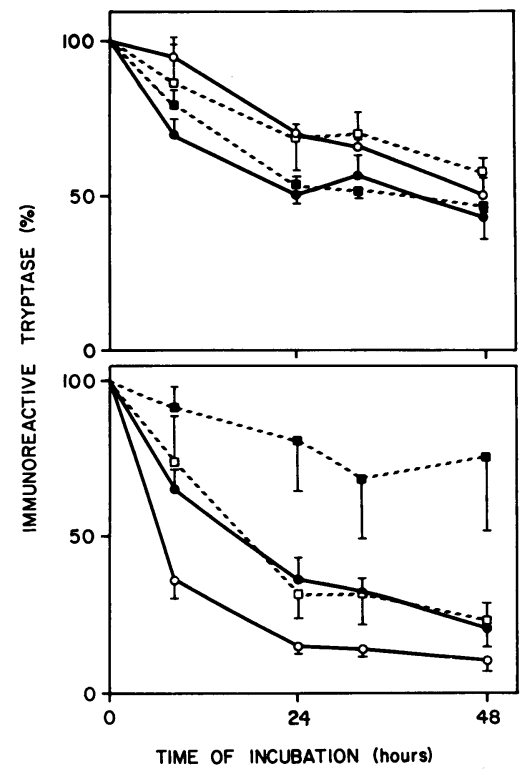

with similar but less sulfated sugar residues and a distinct core protein(s) that may direct its tissue localization.

The time interval after which tryptase appears in the circulation may relate more closely to the time at which signs and symptoms appear than to time of challenge. For example, oral food challenge of sensitive subjects with atopic eczema resulted in a detectable rise in plasma histamine in 11 of 11 clinical responders, with corresponding signs and symptoms occurring anywhere from 30 to 90 min after ingestion of the food (15). Tryptase levels reached a peak $\sim 30$ min after histamine in 8 of 11 subjects. A tryptase assay of greater sensitivity $(<2.5 \mathrm{ng} / \mathrm{ml})$ appears to be needed to detect responders with less intense reactions. Thus, the characteristics of the mast cell agonist as well as its mode of presentation may influence the time of onset of mast cell activation and mediator appearance.

The time course for the decline of tryptase levels follows apparent first order kinetics with a $t_{1 / 2}$ of $1.5-2.3 \mathrm{~h}$ for the venom-challenged subjects, and of $1.5 \mathrm{~h}$ for the indomethacin-challenged individual. The mechanism for removal of tryptase from the circulation is not known. No biologic inhibitors of tryptase that could facilitate its removal have been found $(3,4)$. Whether tryptase enters and resides in the circulation as an active proteoglycan-bound tetramer or as an inactive monomer also is not known $(16,17)$. However, detection of tryptase in the circulation by immunoassay is unrelated to its enzymatic activity and to the presence of proteoglycan. The MAb used in the current tryptase immunoassay recognizes only the inactive form of tryptase, the form into which the enzyme (if not already there) is converted under the conditions of the immunoassay.

Tryptase immunoreactivity is quite stable. Four freezethaw cycles of serum with endogenous enzyme that had been previously frozen and thawed, as well as serum and plasma with exogenously added tryptase that had not been previously frozen or thawed resulted in no significant reduction in mea- sured tryptase. The percentages of endogenous enzyme detected in serum incubated at 22 and $37^{\circ} \mathrm{C}$, respectively, for $4 \mathrm{~d}$ relative to initial values were $140 \pm 21$ (mean \pm SEM) and $100 \pm 26$ (mean \pm SEM). In normal serum with exogenous tryptase, levels declined to 55 and $50 \%$ of initial values after 2 d at 22 and $37^{\circ} \mathrm{C}$, respectively. Levels in plasma declined more rapidly, reaching 20 and $10 \%$ of initial values by $48 \mathrm{~h}$ at 22 and $37^{\circ} \mathrm{C}$, respectively. Whereas the additional presence of heparin in serum had no effect, in plasma this markedly slowed the decline in tryptase levels such that 75 and $24 \%$ of starting tryptase levels were found after $48 \mathrm{~h}$ of incubation at 22 and $37^{\circ} \mathrm{C}$, respectively. The explanation for the apparent higher rate of tryptase turnover in plasma compared with serum is not clear. One component of this turnover rate is blocked by heparin; another component is not blocked by heparin. Tryptase presumably is released from mast cells as a complex with heparin and possibly other mast cell proteoglycans; whether this complex remains intact in the circulation is not known. It is known, for example, that antithrombin III in vitro displaces a portion of tryptase from heparin and may act similarly in vivo. Nearly all of the enzymatic activity of tryptase (proteoglycan free) is known to be lost within the first hour of incubation (16). Thus, the enhanced turnover in plasma presumably reflects an effect on the inactive enzyme. When the enzyme is stored at temperatures of $-20^{\circ} \mathrm{C}$ or lower immunoreactivity appears to be preserved for at least a year. Thus, an elevated tryptase level in serum should not be obscured by freeze-thawing the sample. Allowing specimens to sit at room temperature for periods up to several days may produce false negative results in a group of patients with only modest elevations of enzyme levels.

It seems reasonable, at present, to suggest that the optimal time at which serum/plasma samples for tryptase should be obtained is $1-2 \mathrm{~h}$ after a precipitating event that results in an immediate-type response. When the onset of such symptoms after challenge is delayed, as might occur after food challenge, the optimal time for specimen collection appears to be 30-60 min after onset of symptoms. Depending on the magnitude of the maximal level of tryptase elevated levels of the enzyme are likely to be present in the circulation for several hours. Based on a $t_{1 / 2}$ for removal from the circulation of $\sim 2 \mathrm{~h}$, one would expect levels $>10 \mathrm{ng} / \mathrm{ml}$ for $6 \mathrm{~h}$ after peak levels of $100 \mathrm{ng} / \mathrm{ml}$ and up to $12 \mathrm{~h}$ after peak levels of $800 \mathrm{ng} / \mathrm{ml}$, the maximal serum value observed thus far among patients having systemic anaphylaxis.

It also is important to note the clinical utility of tryptase determinations in several of the individuals from which serum tryptase samples have been obtained. In one case a 56-yr-old white male was being treated for osteoporosis and at least two episodes of vertebral collapse, presumed clinically to be due to a parathyroid dysfunction. Episodes of flushing and hypotension led to a tryptase assessment that was positive, which in turn led to a bone biopsy showing mastocytomas. In a second case a $51 / 2$-yr-old white female had a suspected diagnosis of anaphylaxis during an operative hip procedure confirmed with an elevated level of tryptase, as did a third case of a 31-yr-old white female with idiopathic episodes of flushing and occasional hypotension. An elevated level of tryptase during a presumed anaphylactic reaction to a bee sting in a 36-yr-old black female confirmed this diagnosis. Finding an elevated level of tryptase does not rule out a concomitant vasovagal, septic, or arrythmogenic reaction, but does implicate mast cell activa- 
tion as the primary event because activation of this cell type is not a direct consequence of these other conditions. In addition, induction of severe asthma by nonsteroidal antiinflammatory drugs, such as in the present case with indomethacin, appears to involve mast cell activation (elevated serum levels of tryptase). Thus, immediate hypersensitivity reactions to this class of drug, whether they involve urticaria/angioedema with hypotension as reported previously (1), or asthma alone, appear to be mast cell mediated.

\section{Acknowledgments}

This work was supported in part by National Institutes of Health grants AI-20487 and AI-72621, Virginia Center for Innovative Technology award BI0-87013, and Pharmacia award 87-0697.

\section{References}

1. Schwartz, L. B., D. D. Metcalfe, J. S. Miller, H. Earl, and T. Sullivan. 1987. Tryptase levels as an indicator of mast cell activation in systemic anaphylaxis and mastocytosis. $N$. Engl. J. Med. 316:16221626.

2. Schwartz, L. B., R. A. Lewis, and K. F. Austen. 1981. Tryptase from human pulmonary mast cells: purification and characterization. J. Biol. Chem. 256:11939-11943.

3. Schwartz, L. B., R. A. Lewis, D. Seldin, and K. F. Austen. 1981. Acid hydrolases and tryptase from secretory granules of dispersed human lung mast cells. J. Immunol. 126:1290-1294.

4. Smith, T. J., M. W. Hougland, and D. A. Johnson. 1984. Human lung tryptase, purification and characterization. J. Biol. Chem. 259:11046-11049.

5. Irani, A. M., N. M. Schechter, S. S. Craig, G. DeBlois, and L. B. Schwartz. 1986. Two types of human mast cells that have distinct neutral protease compositions. Proc. Natl. Acad. Sci. USA. 83:44644468.

6. Schwartz, L. B., A. M. Irani, K. Roller, M. C. Castells, and N. M. Schechter. 1987. Quantitation of histamine, tryptase, and chymase in dispersed human MCT and MCTC mast cells. J. Immunol. 138:26112615.
7. Castells, M. C., A. M. Irani, and L. B. Schwartz. 1987. Evaluation of human peripheral blood leukocytes for mast cell tryptase. $J$. Immunol. 138:2184-2189.

8. Smith, P. L., A. Kagey-Sobotka, E. R. Bleecker, R. Traystman, A. P. Kaplan, H. Gralnick, M. D. Valentine, S. Permutt, and L. M. Lichtenstein. 1980. Physiologic manifestations of human anaphylaxis. J. Clin. Invest. 66:1072-1080.

9. Sheffer, A. L., N. A. Soter, E. R. McFadden, Jr., and K. F. Austen. 1983. Exercise-induced anaphylaxis: a distinct form of physical allergy. J. Allergy Clin. Immunol. 71:311-316.

10. Keyzer, J. J., H. Breukelman, B. G. Wolthers, F. J. Richardson, and J. G. de Monchy. 1985. Measurement of $N \tau$-methylhistamine concentrations in plasma and urine as a parameter for histamine release during anaphylactoid reactions. Agents Actions. 16:76-79.

11. Parker, J. L., P. J. Santrach, M. J. E. Dahlberg, and J. W. Yunginger. 1982. Evaluation of Hymenoptera-sting sensitivity with deliberate sting challenges: inadequacy of present diagnostic methods. J. Allergy Clin. Immunol. 69:200-207.

12. Wenzel, S., A. M. Irani, J. M. Sanders, T. R. Bradford, and L. B. Schwartz. 1986. Immunoassay of tryptase from human mast cells. $J$. Immunol. Methods. 86:139-142.

13. Brown, M. J., P. W. Ind, R. Causon, and T. H. Lee. 1982. A novel double-isotope technique for the enzymatic assay of plasma histamine: application to estimation of mast cell activation assessed by antigen challenge in asthmatics. J. Allergy Clin. Immunol. 69:20-24.

14. Schwartz, L. B., P. C. Atkins, T. R. Bradford, P. Fleekop, M. Shalit, and B. Zweiman. 1987. Release of tryptase together with histamine during the immediate cutaneous response to allergen. J. Allergy Clin. Immunol. 80:850-855.

15. Ebbeling, W. L., L. B. Schwartz, and R. W. Buckley. 1988. Comparison of plasma histamine and tryptase levels following double-blind and placebo-controlled food challenges in patients with asthma and/or atopic dermatitis. J. Allergy Clin. Immunol. 81:69. (Abstr.)

16. Schwartz, L. B., and T. R. Bradford. 1986. Regulation of tryptase from human lung mast cells by heparin: stabilization of the active tetramer. J. Biol. Chem. 261:7372-7379.

17. Alter, S. C., P. Yates, H. S. Margolius, and L. B. Schwartz. 1987. Tryptase and kinin generation: tryptase from human mast cells does not activate human urinary prokallikrein. Int. Arch. Allergy Appl. Immunol. 83:321-324. 